\title{
The anti-AChE and anti-proliferative Activities of Glaucium acutidentatum and Glaucium corniculatum Alkaloid Extracts
}

\author{
Fatma Gonca Kocanci*, Buket Hamamcioglu, Belma Aslim \\ Gazi University, Faculty of Science, Department of Biology, 06500 Ankara, Turkey.
}

\begin{tabular}{|c|c|}
\hline ARTICLE INFO & ABSTRACT \\
\hline Article history: & \multirow{10}{*}{$\begin{array}{l}\text { In this study, methanol and water extracts of Glaucium acutidentatum and Glaucium corniculatum were } \\
\text { analysed for anti-AChE activity on neuronal PC12 cell and anti-proliferative activity on HT-29 and HeLa cancer } \\
\text { cells. In this study, total alkaloid, phenol and flavonoid content were analyzed for the determination of active } \\
\text { compounds of Glaucium acutidentatum and Glaucium corniculatum. Indeed, methanol and water alkaloid } \\
\text { extracts of these plants were evaluated for their anti-AChE activities on NGF-differentiated PC12 cells (dPC12) } \\
\text { and anti-proliferative activities on HT- } 29 \text { and HeLa cancer cells. Our data showed that alkaloid was major } \\
\text { compound, the different concentrations of plant extracts had } 35-90 \% \text { in vitro AChE inhibitory activity and 26- } \\
54 \% \text { cellular AChE inhibitory activity and it is dose dependent manner. Furthermore, G. acutidentatum } \\
\text { methanolic extracts showed the highest anti-proliferative activity in HT-29 cells }(45 \pm 5 \%) \text { Both } 1000 \mu \mathrm{g} / \mathrm{ml} \\
\text { methanolic extracts showed the maximum anti-proliferative effect in HeLa cells }(64 \pm 3 \%) \text {. In conclusion, this } \\
\text { study has shown that the anti-AChE and anti-proliferative effects of these two plants and the presence of a new } \\
\text { AChE inhibitor (AChEi) may be effective in AD and cancer. }\end{array}$} \\
\hline $9 / 05 / 2017$ & \\
\hline Accepted on: 0 & \\
\hline Available online: $30 / 08 / 2017$ & \\
\hline Key words: & \\
\hline Glaucium spp., & \\
\hline & \\
\hline & \\
\hline & \\
\hline & \\
\hline
\end{tabular}

\section{INTRODUCTION}

In recent years, there has been an increase in the emergence of serious health problems, including Alzheimer's disease (AD) and cancer. AD was first described by Alois Alzheimer (Alzheimer, 1907). It is a progressive neurodegenerative disease characterized by loss of neuron and synapse in various parts of central nervous system (CNS) and associated with a decrease in the cognitive function and self-care deficiencies (Tayeb et al., 2012). It is the most common form of dementia. As noted in World Alzheimer's Report 2015, there are an estimated 46 million people living with dementia worldwide and the number is expected to be increased up to 74.7 million by 2030 and 131 million by 2050 . It is estimated that the worldwide

* Corresponding Author E-Mail: goncaok@gmail.com;

Phone:+90-312-2021184 Fax:+90-312-2122279 cost of dementia is US $\$ 818$ billion in 2015, which represents $1.09 \%$ of the global gross domestic product (World Alzheimer Report, 2015). Although there are such negative effects of AD, the exact cause(s) is not well-understood and available therapeutic options are limited. Until now, the major mechanism that results in successful symptomatic treatment of $\mathrm{AD}$ is the inhibition of $\mathrm{AChE}$. $\mathrm{AChE}$ is one of the major enzyme which involves in cholinergic nerve transmission and hydrolyzes the neurotransmitter ACh into choline and acetate (Weihe et al., 1996). In AD, the activity of $\mathrm{AChE}$ will be high, resulting in scarcity in the levels of ACh, which ultimately results in the halt of neurotransmission (Syad and Devi, 2014). Furthermore, it has been demonstrated that increased AChE promotes the major neuropathological features of AD (Syad and Devi, 2014).

The existing drugs against $\mathrm{AD}$ are $\mathrm{AChEi}$ : tacrine, donezepil, rivastigmine and galanthamine, all of which have limited effectiveness and some kind of side effect such as 
dizziness, syncope, bradycardia, atrial arrhythmias, myocardial infarction, angina, seizures, sino-atrial and atrioventricular block (Wollen, 2010; Rowland et al., 2007). For this reason, the determination of novel AChE inhibitory agents with fewer side effects which have preventive and therapeutic potential on the AD has attracted researchers' interest and thus becoming an important field of study. Researchers have focused on naturally-occurring compounds from plants as potential sources of either new or more effective AChEi (Murray et al., 2013).

Although AChE is primarily an important member of the cholinergic system, several isoforms of AChE have been identified in various cell and tissue types. AChE has tasks related to cellular proliferation and differentiation besides the classical ACh hydrolysis function in these tissues and cells (Small et al., 1996), which suggests that $\mathrm{AChE}$ is involved in cell proliferation and tumor-genesis. Therefore, the ability to inhibit AChE activity is important for its possible regulatory effects on cancer progression. Some tumor varieties (such as brain, lung, ovarian, breast, hepatocellular, renal and colon cancers) were found, first in the 1980s, to show an over-expression of some cholinesterase activities, especially of acetylcholinesterase (Garaventa et al., 2010). Moreover, studies in recent years have revealed an inverse relationship between cancer and $\mathrm{AD}$ (Roe et al., 2005). These studies have identified that patients with $\mathrm{AD}$ have a reduced risk of cancer and patients with cancer have a reduced risk of AD. Furthermore, studies have proved that some people have both AD and cancer, but are much less common than expected (White et al., 2013). This inverse relationship indicates that AChEi agents may be effective in treating of both $\mathrm{AD}$ and cancer. In addition, the inhibition of AChE is associated with antisense inhibited apoptosis (Xi et al., 2015) and some AChEi suppress the growth of cancer cells and induce mitochondrial pathway of apoptosis in cells (Cheng et al., 2008; $\mathrm{Xu}$ et al., 2014). Further, some chemotherapeutic agents, such as Irinotecan, are used in lung cancer treatment and therapy, acting through the inhibition of AChE activity (Dodds et al., 2001). Most of the chemotherapeutic agents in clinical use are non-selective poisons, resulting in toxicity to normal tissues as well as to tumor cell. For this reason, the development of effective anti-cancer agents has been limited (Hyatt et al., 2005). Despite the advances in modern diagnostic and treatment methods for cancer, there is a need to determine new targets for drug treatment (Grassino, 2013).

For several years, natural products have been used as traditional medicine to treat several diseases and disorders. The bioactive compounds from medicinal plants mainly include steroidal-piperidine-alkaloids derivatives and they play a major role in the slowing of many neurodegenerative and pathogenesis disorders such as AD and cancer (Dhivya et al., 2014; Houghton and Howes, 2005; Wszelaki et al., 2010; Rehman, 2006). In addition, many alkaloids with the inhibitory effect of AChE have various effects on neurological diseases such as AD (Murray et al., 2013; Mukherjee et al., 2007; Mehta et al., 2012; Loizzo et al., 2008). Studies on the effectiveness, tolerance and safety of this alkaloid are ongoing (Zhang, 2012). It has also been shown that alkaloids interact with free radicals and transition metals and enhance the activity of antioxidant enzymes, which are cancer markers (Albarracin et al., 2012).

The Papaveraceae family polarizes the specialists attention because of its pharmaceutical, ornamental and alimentary valences (Bara et al., 2007; Bara et al., 1985; Bohm and Nixdorf, 1983). The species of the Papaveraceae biosynthesize pharmacologically active alkaloids, known to exhibit different pharmacological effects such as anti-tumor, anti-cancer, AChE inhibitory and cytological activities (Sener and Orhan, 2005; Orhan and Sener, 2004). Many species of this family have medicinal and aromatic uses. One of these species is Glaucium corniculatum, known to be traditionally used to treat memory impairment (Ahmed et al., 2013) and have a very high potency of inhibiting AChE (Mehta et al., 2012; Orhan and Sener, 2004; Das et al., 2002; Perry et al., 2001; Perry et al., 2000). Moreover, G. corniculatum stands out with its richness of alkaloid content (Shafiee et al., 1985; Doncheva et al., 2002; Novak et al., 1972; Phillipson et al., 1981; Al-Wakeel et al., 1995). The other is G. acutidentatum. It is endemic to Turkey. Most research to date has focused on the flora of $G$. acutidentatum; there are, however, no published data about the $G$. acutidentatum alkaloid content and its effect on AChE inhibition and cancer. Current studies show that the Glaucium species have AChE inhibitory properties and suggest that the plant is likely to be effective on the AD and cancer. Further, endemic species have attracted the researchers' attention because they may be used for the production of raw materials or preparations containing phytochemicals with health benefits (Exarchou et al., 2002).

The goal of this study was to thoroughly examine the anti-AChE and anti-proliferative activities of methanol and water extracts from Glaucium acutidentatum and Glaucium corniculatum. In this study, the changes of the metabolics composition in methanol and water extracts of plants were determined and the anti-AChE and anti-proliferative potentials of these plants extracts were also compared with their metabolic contents. This is the first report on the relationship between antiAChE and anti-proliferative effects of Glaucium acutidentatum and Glaucium corniculatum alkaloid extracts.

\section{MATERIALS \& METHODS}

\section{Reagents}

High glucose Dulbecco's Modified Eagle's Medium (DMEM), horse serum, foetal bovine serum, L-glutamine, penicillin-streptomycin, acetythiolcholine iodide (ATChI), 5:5dithiobis-2-nitrobenzoic acid (DTNB), AChE from Electrophus electricus (electric eeI), 3-(4, 5-Dimethylthiazol-2-yl)-2, 5diphenyltetrazolium bromide (MTT), $\mathrm{H}_{2} \mathrm{O}_{2}$, bovine serum albumin (BSA), Dimethyl sulfoxide (DMSO), sodium bicarbonate, Tris$\mathrm{HCl}, \mathrm{NaCl}, \mathrm{MgCl}_{2}, 1 \%$ Triton X-100, bradford were reagents purchased from Sigma, UK. 2,5S Nerve Growth Factor (NGF) (Invitrogen, CA). Paraformaldehyde (PFA) and Collagen type I from rat tail were purchased from Merch. 


\section{Plant Material}

Crude plants were collected and verification was done by Prof. Dr. Zeki Aytac, Gazi University, Turkey. G. acutidentatum HAUSSKN. ET BORNM was collected from southwest of Durulmus village of Sivas on 21.06.2013. G. corniculatum (L.) RUD. sub sp. refractum (NAB.) CULLEN was collected from Beypazari district in the northwest of Ankara on 9.07.2012. The names of species are according to International Plant Name Index (IPNI).

\section{Preparation of Plant Extracts}

Above-ground tissues of the plant samples were dried, powdered with an electric grinder and stored in laboratories of the Faculty of Science Department of Biology, Gazi University, Turkey. Plant powders (30 gr) were macerated with $30 \mathrm{~mL}$ of methanol and water, respectively at room temperature for 6 hours with soxhlet device (LabHeat). The extracts were filtered by whatman filter paper and evaporated to dryness $\left(45^{\circ} \mathrm{C}\right)$ under reduced pressure by rotary evaporator (Heidolph Laborota 4000) and stored in a refrigerator at $4^{\circ} \mathrm{C}$ until time of use (Elufioye et al., 2010). The plant extract ( $1 \mathrm{mg}$ ) was dissolved in $1 \mathrm{ml}$ of $2 \mathrm{~N} \mathrm{HCl}$ and filtered with a $0.2 \mu \mathrm{m}$ filter (Shamsa et al., 2008).

\section{Determination of Total Alkaloids in Plant Extracts}

The extracted solution was transferred to a separating funnel, $5 \mathrm{ml}$ of bromocresol green solution and $5 \mathrm{ml}$ of phosphate buffer were added. The mixture was shaken with 1, 2, 3 and $4 \mathrm{ml}$ chloroform. The extracts were collected in a $10 \mathrm{~mL}$ volumetric flask and then diluted to volume with chloroform. A set of reference standard solutions of boldine (100 to $2000 \mu \mathrm{g} / \mathrm{mL}$ ) were prepared in the same manner as described earlier. The absorbance for test and standard solutions were determined against the reagent blank at $470 \mathrm{~nm}$ with an UV/Visible spectrophotometer. The total alkaloid content was expressed as $\mathrm{mg}$ of $\mathrm{AE} / \mathrm{g}$ of extract (Shamsa et al., 2008).

\section{Determination of Total Flavonoid Content in Plant Extracts}

Total flavonoid content was determined according to the aluminium chloride colorimetric method (Lin and Tang, 2007). Each plant extracts $(2 \mathrm{~mL}, 0.3 \mathrm{mg} / \mathrm{mL})$ in solvent were mixed with $0.1 \mathrm{~mL}$ of $10 \%$ aluminium chloride hexahydrate, $0.1 \mathrm{~mL}$ of $1 \mathrm{M}$ potassium acetate and $2.8 \mathrm{~mL}$ of deionized water. After the 40 minutes incubation at the room temperature, the absorbance of the reaction mixture was determined spectrophotometrically at 415 $\mathrm{nm}$. Rutin was chosen as a standard (the concentration range: 5 to $100 \mu \mathrm{g} / \mathrm{mL}$ ) and the total flavonoid content was expressed as milligram $\mathrm{RE} / \mathrm{g}$ of extracts.

\section{Determination of Total Phenolic Content in Plant Extracts}

The total phenolic content in the plant extracts was determined spectrophotometrically according to the FolinCiocalteu method (Singleton et al., 1999) using galic acid as a standard (the concentration range: 25 to $500 \mu \mathrm{g} / \mathrm{mL}$ ). The reaction mixture was prepared by mixing $1 \mathrm{~mL}$ of the methanolic solution (concentration $0.3 \mathrm{mg} / \mathrm{mL}$ ), of the methanolic solution of the extract, $9 \mathrm{~mL}$ of distilled water, $1 \mathrm{~mL}$ of Folin-Ciocalteu reagent and $10 \mathrm{~mL}$ of $7 \%$ sodium carbonate. After the 90 minutes incubation at room temperature, the absorbance was determined spectrophotometrically at $765 \mathrm{~nm}$. The total phenolic content was expressed as GAE in milligram per gram dry extract.

\section{Assay for in vitro AChE Inhibitory Activity}

Inhibition of in vitro AChE activity was assayed as described by Ellman et al. (1961) with some modifications. The plant extracts were tested in $100,250,500$ and $1000 \mu \mathrm{g} / \mathrm{mL}$ concentrations. $20 \mu \mathrm{L}$ of $0.5 \mu \mathrm{g} / \mathrm{mL}$ AChE in $0.1 \mathrm{M}$ phosphate buffer, $\mathrm{pH} 8$ and $100 \mu \mathrm{L}$ of the sample dissolved in the DMEM, 50 $\mu \mathrm{L}$ of $0.495 \mathrm{mg} / \mathrm{mL} 5,5$ '-Dithiobis-(2-Nitrobenzoic Acid) (DTNB) (which was dissolved with $1 \mathrm{~mL}$ of $0.1 \mathrm{M}$ phosphate buffer, $\mathrm{pH} 8$, containing $0.1875 \mathrm{mg} / \mathrm{mL}$ sodiumbicarbonate $\left(\mathrm{NaHCO}_{3}\right)$ ) were added to each of 96 wells. The plates were incubated for 10 minutes at room temperature in dark area before the addition of 50 $\mu \mathrm{L}$ of $0.542 \mathrm{mg} / \mathrm{mL}$ substrate solution (S-Acetyl thiocholine Iodide) (was dissolved in $1 \mathrm{~mL}$ distill water) to the reaction mixture. The absorbance of the yellow 5-thio-2-nitrobenzoate anion produced was measured at a wavelength of $412 \mathrm{~nm}$ using Epoch Take 3 Plate microplate reader after 10 minutes. Enzyme activity was calculated as a percentage compared to an assay using a buffer without any inhibitor. Galantamine was used as positive control. Percentage enzyme inhibition was calculated by comparing the enzymatic activity with and without inhibitor.

\section{Cell Cultures}

PC12 cell line was derived from a transplantable rat pheochromocytoma (Greene and Tischler, 1976). A notable feature of PC12 cells is that they respond to NGF. In response to NGF, PC12 cells are converted from proliferating chromaffin-like cells to nondividing sympathetic-neuron-like cells that extend axons and become electrically excitable (Greene, 1978; Greene and Rein, 1977). Because of these, PC12 cells are well-defined models to work on cellular biology of neurons and widely used to investigate the mechanism comprising neuronal repair, neuronalsubstratum interactions, oxidative stress responses, neuroprotective activity, neurotoxicity and pathogenesis of neuronal diseases, including AD (Fedoroff and Richardson, 2001; Ma et al., 2009; Sandhu, 1993; Fath et al., 2002; Sambamurti et al., 1992; Calissano et al., 2009). In addition, PC12 cells were used as model in studies investigating the AChE inhibitory properties of various substances (Das and Barone, 1999; Zhang and Tang, 2000; Wang et al., 2013; Pera et al., 2013).

PC12 cells (CRL-1721 TM) were obtained from Gazi University, Biotechnology Laboratory Collection. The cells were grown at $37^{\circ} \mathrm{C}\left(5 \% \mathrm{CO}_{2}\right)$ in growth medium: Dulbecco's modified Eagle's medium (DMEM) with $4.5 \%$ glucose containing $10 \%$ horse serum and $10 \%$ foetal bovine serum, supplemented with penicillin/streptomycin $(100 \mathrm{U} / \mathrm{ml}) /(100 \mu \mathrm{g} / \mathrm{ml})$, L-glutamine (200 $\mathrm{mM})$. The medium steriled and filtered with a $0.2 \mu \mathrm{m}$ filter. PC12 cells were seeded onto $\mathrm{T}-75 \mathrm{~cm}^{2}$ flasks (Corning, NY, USA) 
coated with $50 \mathrm{ng} / \mathrm{ml}$ rat tail collagen, to achieve $70 \%$ confluence. The cells from passages $8-10$ were used. The cells were split every other day at a ratio of about 2:3. Neuronal differentiation was initiated by the addition of $100 \mathrm{ng} / \mathrm{ml} \mathrm{NGF}$ in growth medium. Differentiation medium was refreshed every two days (Jacovina et al., 2001). HeLa (human cervical cancer) (CCL-2 ${ }^{\mathrm{TM}}$ ) and HT-29 (human colon cancer) (HTB-38 ${ }^{\mathrm{TM}}$ ) cell lines, the most commonly used for testing agents that may have anti-proliferative effect were purchased from ATCC. They were cultured in $75 \mathrm{~cm}^{2}$ flasks in DMEM with $4.5 \%$ glucose containing supplemented with $10 \%$ fetal bovine serum, penicillin/ streptomycin $(100 \mathrm{U} / \mathrm{ml}) /(100 \mu \mathrm{g} / \mathrm{ml})$, L-glutamine $(200 \mathrm{mM})$. The media was sterilized by $0.2 \mu \mathrm{m}$ filter and the cells were grown at $37{ }^{\circ} \mathrm{C}$ in an environment of $5 \% \mathrm{CO}_{2}$. Cell counts were performed by Trypan blue exclusion method using haemocytometer slide (Jafarian et al., 2014; Mahmoudi et al., 2009).

\section{Control of the Morphology and Differentiation of PC12 Cells}

To control PC12 cells differentiation, the cells were grown on the Poly-D-Lysine and laminin coated cover slips with differentiation medium. The cover slips were fixed second, fourth and sixth days in $3.7 \%$ para-formaldehyde (PFA) for 15-20 minutes at room temperature and subsequently washed in 1xPBS. The cells were viewed using a light microscope (LEICA ICC50 HD, LAS V4.3.0 program). The cells were regarded as differentiated when the neurite length was more than two cell bodies (Ignatius et al., 1985).

\section{Cytotoxicity Assay}

In order to determine the toxicity of $\mathrm{H}_{2} \mathrm{O}_{2}$ and plant extracts on PC12 cells, the cells were plated on to collagen-coated 96-well plates at a density of $1 \times 10^{4}$ cells/well at $37^{\circ} \mathrm{C}$ in $95 \%$ humidified air with $5 \% \mathrm{CO}_{2}$. dPC12 cells were treated with 50, 100 and $250 \mu \mathrm{M} \mathrm{H}_{2} \mathrm{O}_{2}$ for $6,12,24,48 \mathrm{~h}$ and treated with 100,250 , 500 and $1000 \mu \mathrm{g} / \mathrm{ml}$ plant extracts for 4, 10 and 24h which were diluted with differentiation medium. For the control cells, differentiation medium was used instead of the extract solutions.

In order to determine the anti-proliferative activity of plant extracts on two human cancer cell lines (HT-29 and HeLa), the cells were plated on 96-well plates at a density of $1 \times 10^{4}$ cells/well at $37^{\circ} \mathrm{C}$ in $95 \%$ humidified air with $5 \% \mathrm{CO}_{2}$ and treated with 500 and $1000 \mu \mathrm{g} / \mathrm{ml}$ plant extracts for $24 \mathrm{~h}$ which were diluted with medium.

In vitro cytotoxicity was measured by the method of MTT described by Mosmann (1983) (Mosmann, 1983). This is a colorimetric assay that measures the reduction of yellow (3- $(4,5$ dimethylthiazolyl-2) -2, 5-diphenyltetrazolium bromide) (MTT) by mitochondrial succinate dehydrogenase. The MTT enters into the cells and passes into the mitochondria where it is reduced to an insoluble, coloured (dark purple) formazan product measured spectrophotometrically. Since the reduction of MTT can occur only in metabolically active cells, the level of activity is a measure of the viability of the cells. After the treatments of the cells, $20 \mu \mathrm{l}$ of MTT $(5 \mathrm{mg} / \mathrm{ml})$ in distilled $\mathrm{H}_{2} \mathrm{O}$ was added to each well. The plates were gently shaken and incubated for $4 \mathrm{~h}$ at $37^{\circ} \mathrm{C}$ in $5 \% \mathrm{CO} 2$ incubator. After the removal of the medium containing MTT, 200 $\mu \mathrm{L}$ DMSO was added to each well. The plates were gently shaken to solubilize the formed formazan. Percent cell survival in the control group was assumed 100. The optical density was measured at $570 \mathrm{~nm}$ on a microplate reader. The $\%$ cell viability was determined using this formula:

$\%$ Cell viability $=($ Sample absorbance $) /($ control absorbance $)$ X 100

Control cells were cultured with neither plant extract nor $\mathrm{H}_{2} \mathrm{O}_{2}$ treatment.

IC50 (50\% inhibition of cell growth) value was calculated using a no linear regression log (inhibitor) versus responsevariable slope graph.

\section{Determination of Cellular AChE Activity}

PC12 cells were plated on to collagen-coated 96-well plates at a density of $1 \times 10^{4}$ cells/well at $37^{\circ} \mathrm{C}$ in $95 \%$ humidified air with $5 \% \mathrm{CO}_{2}$. After the cells were differentiated, they were exposed to 50 and $100 \mu \mathrm{M} \mathrm{H}_{2} \mathrm{O}_{2}$ for $6,12,24$ and $48 \mathrm{~h}$. After the $\mathrm{H}_{2} \mathrm{O}_{2}$ withdrawal, the cells were cultured in differentiation medium containing $1000 \mu \mathrm{g} / \mathrm{ml}$ plant extracts for 24h. To obtain total protein of the application made $\mathrm{dPC} 12$ cells, the cultures were washed twice with cold phosphate-buffered saline (PBS), scraped, and then the cell suspension was taken into $1.5 \mathrm{ml}$ tubes, the tubes were centrifuged at $10,000 \mathrm{Xg}$ for $5 \mathrm{~min}$ at $4^{\circ} \mathrm{C}$. PBS was discarded withdrawn. The cell pellets were lysed in solubilisation buffer (pH 7.8) (10 mM Tris-HCl, pH 7.2, $1 \mathrm{M} \mathrm{NaCl}, 50 \mathrm{mM}$ $\mathrm{MgCl}_{2}, 1 \%$ Triton X-100) (Schwartz et al., 2007). The homogenates were kept on ice for 30 minutes and vortexed briefly every 5 minutes. Following centrifugation of the homogenates $\left(20,000 \mathrm{Xg}\right.$ for $30 \mathrm{~min}$ at $\left.4^{\circ} \mathrm{C}\right)$, the supernatants were removed on ice. The total protein concentration, present in the extracts, was assayed according to the Bradford method (Bradford, 1977) with bovine serum albumin (BSA) as standard. The remaining protein was stored at $-80^{\circ} \mathrm{C}$ until enzymatic analysis. Relative $\mathrm{AChE}$ activity was measured colorimetrically using a modified method of Ellman et al. (1961) which was adapted for 96 well plates. Relative AChE activity was measured with an equal amount of total protein. Briefly, equal amount of total protein, $100 \mu \mathrm{L}$ of solubilisation buffer ( $\mathrm{pH} 7.8$ ) and $50 \mu \mathrm{L}$ of $0.495 \mathrm{mg} / \mathrm{ml} \mathrm{DTNB}$ (which was dissolved with $1 \mathrm{ml}$ of $0.1 \mathrm{M}$ phosphate buffer, $\mathrm{pH} 8$, containing $0.1875 \mathrm{mg} / \mathrm{ml} \mathrm{NaHCO}$ ) were added to each of 96 wells and the plate was pre-incubated for 10 minutes at room temperature in a dark place. The reaction was started by the addition of $50 \mu \mathrm{L}$ of $0.542 \mathrm{mg} / \mathrm{ml} \mathrm{ATCh}$ (was dissolved in $1 \mathrm{ml}$ distill water). 10 minutes later, AChE enzyme activity was determined by the absorbance value, measured at a wavelength of $412 \mathrm{~nm}$. The AChE activity was expressed as multiple relative to untreated control and enzyme activity was determined by the formula:

Relatively AChE activity $=($ Sample absorbance $) /($ control absorbance) X 100 


\section{Statistical Analysis}

The statistical analyses were carried out using $t$ test with $P<0.05$ considered to be significant. The differences between the untreated control group and treated group were determined by ttest whereas IC50 (50\% inhibition of cell growth) value was calculated using a no linear regression log (inhibitor) versus response-variable slope graph. Pearson's correlation coefficient test was used to assess correlations between the means.

\section{RESULTS AND DISCUSSIONS}

\section{Total Alkaloid, Flavonoid and Phenolic Contents}

The alkaloid contents were expressed in terms of boldine equivalent as $\mathrm{mg}$ of $\mathrm{AE} / \mathrm{g}$ of extract (the standard curve equation: $\left.\mathrm{y}=1.3026 \mathrm{x}-0.0176, \mathrm{R}^{2}=0.9924\right)$. The content of flavonoids was expressed in terms of rutin equivalent (the standard curve equation: $\left.\mathrm{y}=0.024 \mathrm{x}+0.0556, \mathrm{R}^{2}=0.9916\right), \mathrm{mg}$ of $\mathrm{RE} / \mathrm{g}$ of extract. Gallic acid was used as a standard compound and the total phenolic contents were expressed as $\mathrm{mg} / \mathrm{g}$ gallic acid equivalent using the standard curve equation $\left(\mathrm{y}=0.0318 \mathrm{x}-0.4032, \mathrm{R}^{2}=\right.$ 0.9976).

In all plant extracts, alkaloid was found to be the major compound and flavonoid and phenolic contents were less than a substantial degree (Table 1).

This result is in agreement with Shafiee et al. (1985) and Novak et al. (1971), reporting that the Glaucium genus stand out with its richness of alkaloid content.

Table 1: Total alkaloid, flavonoid and phenol contents of G. acutidentatum and G. corniculatum extracts.

\begin{tabular}{llll}
\hline \multicolumn{1}{|c}{ Plant Extracts } & $\begin{array}{c}\text { Total } \\
\text { alkaloid } \\
\text { content }(\mathbf{m g} \\
\mathbf{A E} / \mathbf{g}) \text { of } \\
\text { extracts }\end{array}$ & $\begin{array}{c}\text { Total } \\
\text { flavonoid } \\
\text { content }(\mathbf{m g} \\
\mathbf{R E} / \mathbf{g}) \text { of } \\
\text { extracts }\end{array}$ & $\begin{array}{c}\text { Total phenolic } \\
\text { content }(\mathbf{m g} \\
\text { GAE/g) of } \\
\text { extracts }\end{array}$ \\
\hline G. acutidentatum & & & \\
\hline Methanol & $98.77 \pm 0.01^{\mathrm{a}}$ & $0.70 \pm 0.02^{\mathrm{a}}$ & $1.84 \pm 0.09^{\mathrm{a}}$ \\
Water & $84.79 \pm 0.04^{\mathrm{b}}$ & $1.00 \pm 0.02^{\mathrm{a}}$ & $1.62 \pm 0.05^{\mathrm{a}}$ \\
\hline G. corniculatum & & & \\
\hline Methanol & $100.61 \pm 0.06^{\mathrm{c}}$ & $0.80 \pm 0.04^{\mathrm{a}}$ & $1.63 \pm 0.03^{\mathrm{a}}$ \\
\hline Water & $76.65 \pm 0.09^{\mathrm{d}}$ & $1.20 \pm 0.04^{\mathrm{a}}$ & $1.60 \pm 0.06^{\mathrm{a}}$ \\
\hline Values expressed as mean \pm SD. Data with different superscript letters along \\
the same column are statistically different $(P<0.05)$.
\end{tabular}

The total alkaloid content in different extracts were compared according to the statistical calculation and the results showed all the studied alkaloid contents varied according to plant species and extraction solvent. In both plant species, methanol extracts contain more alkaloid compared to water. The methanol extract of $G$. corniculatum was the highest amount of total alkaloid (100.61 mg AE/g) and water extract of G. corniculatum had the least content $(76.65 \mathrm{mg} \mathrm{AE} / \mathrm{g})$. It is known that secondary metabolites vary in their behavior in organic solvents because they have different chemical structures. Although both free and salt alkaloids can be dissolved in various solvents, many alkaloids dissolve poorly in water but readily dissolve in organic solvents, such as methanol (Babbar, 2015).

\section{In vitro Inhibition of $\mathrm{AChE}$}

Using Ellman's colorimetric assay, all the tested water and methanol extracts of plants demonstrated AChE inhibitory properties in a dose dependent manner. The results show that all of the extracts at $1000 \mu \mathrm{g} / \mathrm{mL}$ displayed high anti-AChE activity for all species (Table 2). The tested extracts were found to have AChE inhibitory properties at varying rates of $35-90 \%$ depending on the concentration. $G$. corniculatum methanol extract showed a higher AChE inhibitory effect $(90 \pm 2 \%)$ and $G$. acutidentatum water extract showed a lower AChE inhibitory effect $(78 \pm 1 \%)$ at 1000 $\mu \mathrm{g} / \mathrm{mL}$.

Table 2: The in vitro AChE inhibitory activity of the G. acutidentatum and $G$. corniculatum extracts.

\begin{tabular}{lcccc}
\hline \multicolumn{4}{c}{ AChE Inhibition $(\%)$} \\
\hline Plant Extracts & $\mathbf{1 0 0}$ & $\mathbf{2 5 0}$ & $\mathbf{5 0 0}$ & $\mathbf{1 0 0 0}$ \\
\hline G. acutidentatum & & & & \\
Methanol & $38 \pm 1^{\mathrm{a}}$ & $47 \pm 1^{\mathrm{a}}$ & $53 \pm 2^{\mathrm{a}}$ & $85 \pm 1^{\mathrm{a}}$ \\
Water & $35 \pm 1^{\mathrm{a}}$ & $39 \pm 2^{\mathrm{b}}$ & $45 \pm 0^{\mathrm{b}}$ & $78 \pm 1^{\mathrm{b}}$ \\
\hline G. corniculatum & & & & \\
Methanol & $59 \pm 0^{\mathrm{b}}$ & $72 \pm 2^{\mathrm{c}}$ & $77 \pm 1^{\mathrm{c}}$ & $90 \pm 2^{\mathrm{a}}$ \\
Water & $52 \pm 1^{\mathrm{c}}$ & $60 \pm 1^{\mathrm{d}}$ & $68 \pm 1^{\mathrm{d}}$ & $89 \pm 3^{\mathrm{a}}$ \\
Galantamine $^{*}$ & $88 \pm 3$ & $88 \pm 1$ & $92 \pm 2$ & $93 \pm 2$ \\
\hline
\end{tabular}

Values expressed as mean \pm SD. *Positive control. Data with different superscript along the same column are statistically different $(P<0.05)$.

Glaucium species have a very high potency of inhibiting AChE (Mehta et al., 2012; Orhan and Sener, 2004; Das et al., 2002; Perry et al., 2001; Perry et al., 2000). In a study conducted by Orhan et al., (2004), chloroform: methanol (1:1) extracts of $G$. corniculatum manifested $86.55 \%$ AChE inhibition at $1000 \mu \mathrm{g} / \mathrm{ml}$. On the contrary, not much work has been done on the anti-AChE activity of $G$. acutidentatum. Our results are consistent with the previous studies showing the effect of $G$. corniculatum on AChE inhibition. In addition, it is the first study to show that $G$. acutidentatum is an $\mathrm{AChE}$ inhibitor.

In this study, the $1000 \mu \mathrm{g} / \mathrm{mL}$ of $G$. corniculatum extract was found to show an AChE inhibitory activity similar to that of the positive control galanthamine. A study made by Mohsen et al., (2015) determined that $1 \mathrm{mM}$ of donepezil showed $99.01 \pm 4.89 \%$ AChE inhibitory effect (Mohsen et al., 2015). In a study in which rivastigmine at $40 \mathrm{mg} / \mathrm{ml}$ was used as the standard, almost $66 \%$ AChE inhibitory activity was identified (Somani et al., 2015). In a study conducted in the same manner, 66\% AChE inhibitory activity of $1000 \mu \mathrm{g} / \mathrm{ml}$ of physostigmine (eserine) was determined (Rodrigues et al., 2014). Mandegary et al., (2014) determined that $2 \mu \mathrm{g} / \mathrm{ml}$ of tacrine showed $86.37 \pm 3.24 \%$ AChE inhibitory effect. According to these results, $G$. corniculatum and $G$. acutidentatum alkaloid extracts showed a higher AChE inhibitory effect than some AChE inhibitor drugs approved for the treatment of AD. 
Table 3: The effect of plant extracts on cell viability of PC12.

\begin{tabular}{|c|c|c|c|}
\hline & & $\left(\mathbf{I C}_{50}\right)(\boldsymbol{\mu g}$ & \\
\hline Plant Extracts & 4 hour & 10 hour & 24 hour \\
\hline \multicolumn{4}{|l|}{ G. acutidentatum } \\
\hline Methanol & $1326 \pm 4^{\mathrm{a}}$ & $1080 \pm 3^{\mathrm{a}}$ & $979 \pm 4^{\mathrm{a}}$ \\
\hline Water & $2775 \pm 4^{\mathrm{b}}$ & $2434 \pm 4^{\mathrm{b}}$ & $1383 \pm 7^{\mathrm{b}}$ \\
\hline \multicolumn{4}{|l|}{ G. corniculatum } \\
\hline Methanol & $1982 \pm 3^{c}$ & $1403 \pm 1^{\mathrm{c}}$ & $1203 \pm 2^{c}$ \\
\hline Water & $1830 \pm 2^{d}$ & $1494 \pm 3^{c}$ & $1166 \pm 3^{\mathrm{d}}$ \\
\hline
\end{tabular}

Values expressed as mean \pm SD. Data with different superscript along the same column are statistically different $(P<0.05)$.

\section{Morphological Control and Differentiation of PC12 Cells}

Neurons are morphologically polarized cells and they have extensions reaching from the cell body to the periphery. Extensions are defined as neurites when reaches twice the diameter of the cell body (Van Ooyen, 2005). According to neurite size analyzes performed on an average of 100 cells, baseline neurite densities and differentiation percentages of PC12 cells treated with $100 \mathrm{ng} / \mathrm{ml} \mathrm{NGF}$ were analyzed on the 2nd, 4th and 6th day of differentiation. In parallel with differentiation times, the increase in neurite lengths of PC12 cells was found to be statistically significant. On the fourth day, neurites started to form and on the 6th day differentiation was observed. $100 \mathrm{ng} / \mathrm{ml}$ NGF for 6 days was used in subsequent studies.

\section{Effects of $\mathrm{H}_{2} \mathrm{O}_{2}$ on Cell Viability of PC12 Cells}

$\mathrm{PC} 12$ cell culture was used for the cell viability tests of $\mathrm{H}_{2} \mathrm{O}_{2} . \quad \mathrm{H}_{2} \mathrm{O}_{2}$ did not show any significant cytotoxic effects at concentrations ranging from 50 to $100 \mu \mathrm{M}$ for $6,12,24 \mathrm{~h}$, whereas cell survival was significantly decreased at a concentration $>100$ $\mu \mathrm{M}$. In addition, high mortality rates were observed after $48 \mathrm{~h}$ of application (data not shown). Therefore, the 50 and $100 \mu \mathrm{M}$ concentrations of $\mathrm{H}_{2} \mathrm{O}_{2}$ were used for $24 \mathrm{~h}$ in the subsequent experiments.

\section{Effects on Cell Viability of Glaucium spp. Extracts}

In our experiments, in general, IC50 values of plant extracts applied to PC12 cells for 4, 10 and 24 hours were found to be high $(>1000 \mu \mathrm{g} / \mathrm{ml})$. The results of cell viability are presented in Table 3. According to the U.S. NCI plant screening program, a crude extract is generally considered to have in vitro cytotoxic activity with an IC50 value $\leq 20 \mu \mathrm{g} / \mathrm{mL}$ (Sriwiriyajan et al., 2014). Consequently, all the extracts demonstrated less toxicity on PC12 cells. These results have proven that Glaucium extracts do not cause AChE inhibition resulting from cell death in PC12 cells.

\section{Effects on Cellular AChE Activity of Glaucium spp. Extracts}

We showed that AChE activity did not increase effectively in $\mathrm{PC} 12$ cells treated with $50 \mu \mathrm{M} \mathrm{H}_{2} \mathrm{O}_{2}$. However, PC12 cells treated with $100 \mu \mathrm{M} \mathrm{H}_{2} \mathrm{O}_{2}$ for 24 hours showed a significant increase in AChE activity $(152 \pm 2 \%$ AChE activity) when compared to the control (data not shown). Therefore, this concentration was selected to evaluate the potential protective effects of Glaucium extract on $\mathrm{H}_{2} \mathrm{O}_{2}$ induced $\mathrm{AChE}$ increase in PC12 cells.

We investigated whether Glaucium extracts could inhibit the increased activity of AChE induced by $\mathrm{H}_{2} \mathrm{O}_{2}$ in $\mathrm{dPC} 12$ cells. The cells were primarily incubated with $100 \mu \mathrm{M}$ of $\mathrm{H}_{2} \mathrm{O}_{2}$ for $24 \mathrm{~h}$ and then treated with $1000 \mu \mathrm{g} / \mathrm{ml}$ plant extracts for 24 hour.

AChE activity levels were more than $50 \%$ higher in $\mathrm{H}_{2} \mathrm{O}_{2}$ treated group when compared to the control. AChE activity at dPC12 cells treated with plant extract was significantly decreased when compared to $\mathrm{H}_{2} \mathrm{O}_{2}$ treated group. All the plant extracts prevented an increase in AChE activity in $\mathrm{H}_{2} \mathrm{O}_{2}$ treated dPC12 cells. Both methanol and water extracts of G. acutidentatum had higher AChE inhibitory action compared to G. corniculatum extracts. The methanol extract of G. acutidentatum showed the most strong inhibitory effects of the activity of AChE, with AChE activity decreased to $71 \pm 2 \%$. However, the water extract of $G$. acutidentatum decreased the $\mathrm{AChE}$ activity to $81 \pm 3 \%$, while methanol and water extracts of $G$. corniculatum decreased to $105 \pm 5 \%, 116 \pm 4 \%$, respectively (Fig. 1). According to the findings, in vitro and cellular AChE inhibitory effect is related to alkaloid due to negligible amounts of total phenolic and flavanoid contents in the extracts. High amounts of alkaloid and AChE inhibitory effect relative to water observed for methanol extracts also support the finding above. These findings indicate that the $\mathrm{AChE}$ activity increased in PC12 cells treated with $\mathrm{H}_{2} \mathrm{O}_{2}$, and suggest that all extracts that have anti-AChE effects and protective effect against AChE increase caused by $\mathrm{H}_{2} \mathrm{O}_{2}$ on $\mathrm{PC} 12$ cells.

Many alkaloids have an inhibitory effect of $\mathrm{AChE}$ and have various effects on diseases such as $\mathrm{AD}$ and cancer (Naaz et al., 2013; Lu et al., 2012). Comparison of the amount of total alkaloids results with its cellular AChE inhibitory activity showed no significant correlation in our study. Although G.corniculatum have the highest total amount of alkaloids, it has less cellular AChE inhibitory activity according to G. acutidentatum. Indeed, due to different $\mathrm{AChE}$ inhibition potentials of different compounds, the AChE inhibition activity of extract strongly dependents on the extraction solvent (Obregon et al., 2005). These differences are due to the content and quality of the alkaloids in the different solvent. These results suggest that synergism between the alkaloids in the extracts and the anti-AChE activity is dependant not only on the concentration but also on the structure of alkaloids. 


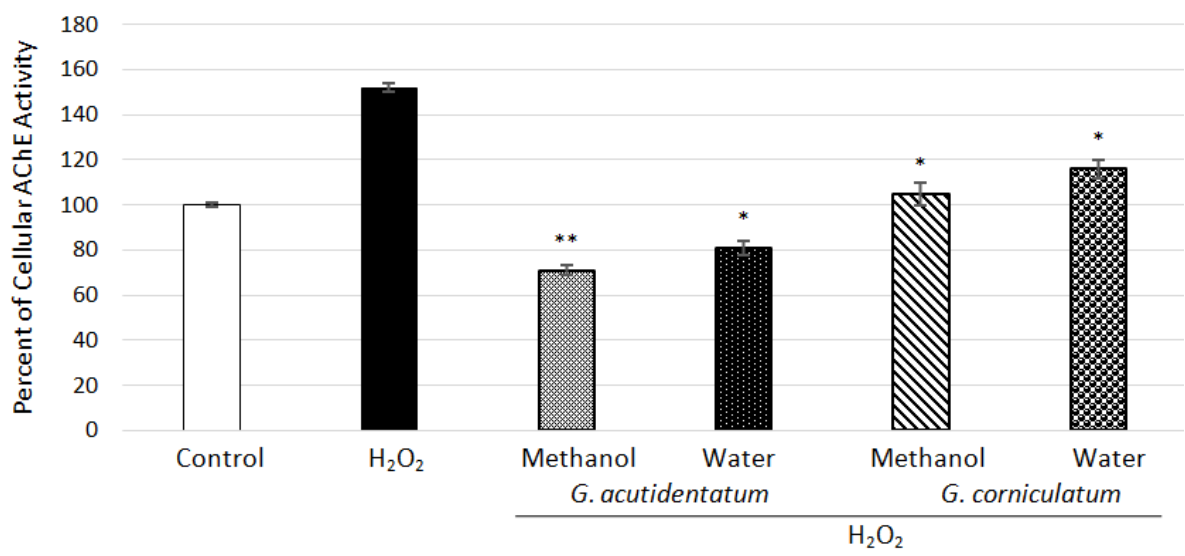

Fig. 1: The effect of $\mathrm{H}_{2} \mathrm{O}_{2}$, G. acutidentatum and G. corniculatum alkaloid extracts on AChE activity of dPC12. Control: dPC12 cells grown in normal culture conditions Values were expressed as mean $\pm \mathrm{SD}$. Statistical significance was taken at a $\mathrm{P}$ value $<0.05$. ${ }^{\#} P<0.05$ v. vehicle control. $* P<0.05$ v. $100 \mu \mathrm{M} \mathrm{H}_{2} \mathrm{O}_{2}$ treatment for $24 \mathrm{~h}$ alone. $* * P<0.001$ v. $100 \mu \mathrm{M} \mathrm{H}_{2} \mathrm{O}_{2}$ treatment for $24 \mathrm{~h}$ alone

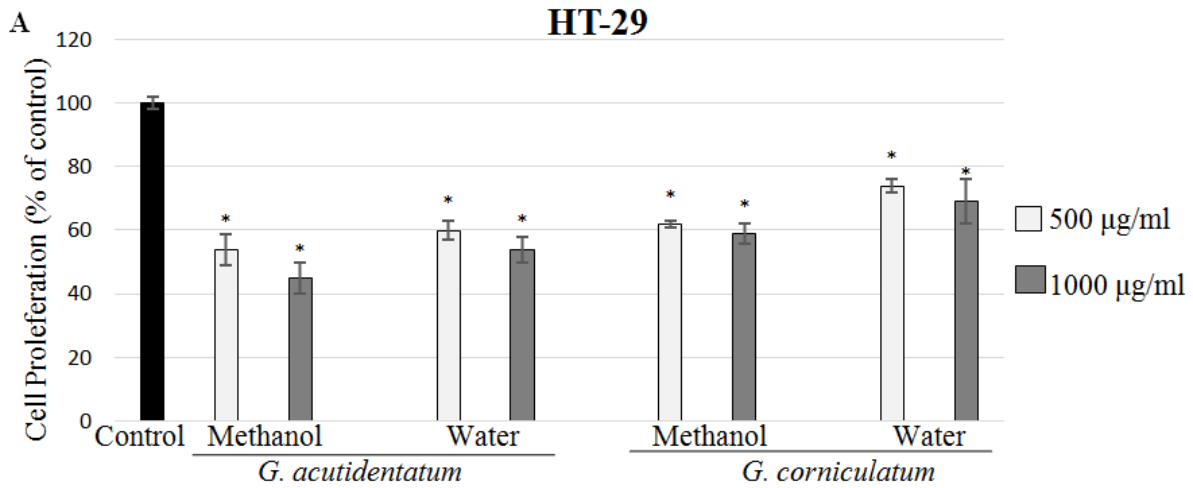

B

HeLa

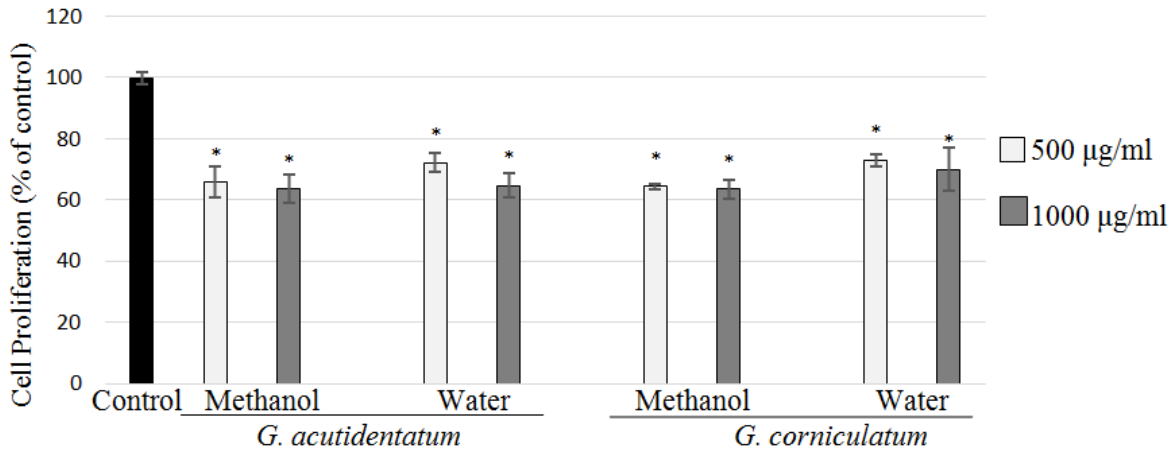

Fig. 2: The anti-proliferative effect of G. acutidentatum and G. corniculatum alkaloid extracts on HT-29 (A) and HeLa (B) cells. Control: HT 29 and HeLa cells grown in normal culture conditions Values were expressed as mean $\pm \mathrm{SD}$. Statistical significance was taken at a $\mathrm{P}$ value $<0.05$. $* P<0.05 \mathrm{v}$. vehicle control.

\section{Anti-proliferative Effect of Glaucium spp. Extracts}

The anti-proliferative activity of the plant alkaloid extracts on two types of cancer cell lines were expressed by the percentage of cell viability (Figure 2). Based on the report by Fouche et al. (2008) the anti-proliferative activities of the extracts were categorized according to the percent decrease in cell viability into four groups: inactive (1-20\%), weakly active (20-50\%), moderately active (50-70\%) or very active (70-100\%). Methanol extract of $G$. acutidentatum were moderately active against HT-29 cells at $1000 \mu \mathrm{g} / \mathrm{ml}$ with $55 \pm 5 \%$ decrease in cell viability and the others were weakly active (Fig 2A). Both methanol and water extracts showed maximal anti-proliferative effect at $1000 \mu \mathrm{g} / \mathrm{ml}$ dose in HeLa cells, with cell viability decreased to $64 \pm 3 \%$ of the control cells (Fig.2B). Hence, on the overall, plant extracts showed a higher anti-proliferative effect in HT-29 cells than HeLa cells. When compared to the extract types, methanol extracts showed more anti-proliferative activity than water extracts in HT29 and HeLa cells. The same signals may produce different responses in different cell types. This 'cell specificity' is due to the specific receptors and intracellular signalling molecules that are active in different cell types. There are some possible mechanisms for the formation of different cell-specific outcomes against the 
same stimulus. One of this, the signal activation level and the effector processing mechanism could be cell specific (MillerJensen et al., 2007). The fact that plant extracts have a higher antiproliferative effect in HT-29 than HeLa cells may be associated with cell-type specificity. These outcomes were consistent with the results of the cellular AChE inhibition and showed that $G$. acutidentatum and G. corniculatum extracts had anti-AChE and anti-proliferative activity. Although many results show that AChE activities are increased in cancer patients, conflicting results have been found (Montenegro et al., 2006; Zhang et al., 2002; Martínez-López de Castro et al., 2008; Jin et al., 2004). There are studies that show that AChE activity decreases in lung cancer, which may contribute to lung cancer growth. Zhao et al. demonstrated that the expression of AChE was significantly decreased in the cancer tissues of $69.2 \%$ of hepatocellular carcinoma (HCC) patients, and the low expression level of AChE in HCC was correlated with tumor aggressiveness, the increased risk of postoperative recurrence, low survival rate, and poor prognosis (Zha et al., 2011). For this reason, the functions of $\mathrm{AChE}$ in different cell types need to be further investigated.

Linear regression analysis proved that cellular anti-AChE activity and anti-proliferative activity showed negative correlation with total alkaloid amount. However, there was a strong relationship between the cellular anti-AChE and anti-proliferative activity $\left(r=0.960, r^{2}=0.922\right)$. Therefore, the inhibition of cancer cell proliferation and $\mathrm{AChE}$ by the extracts may be partial due to the amount of their alkaloid content but might be attributed to the diversification of alkaloid types. Further, these results demonstrate that determination of in vitro $\mathrm{AChE}$ inhibition is not sufficient alone for the exploration of $\mathrm{AChEi}$, for there was a negative correlation between the in vitro and cellular AChE inhibitory activity.

\section{CONCLUSION}

We successfully demonstrated the anti-AChE and antiproliferative activities of methanol and water extracts of $G$. acutidentatum and G. corniculatum.

All of the Glaucium alkaloid extracts used in our study provide AChE inhibition without damaging the PC12 cells. These results bring attention to the inhibitory effects of the Glaucium species on $\mathrm{AChE}$ and can explain why this plant is considered as a traditional medicinal plant. In addition, the alkaloid extracts of $G$. acutidentatum and $G$. corniculatum have potential antiproliferative activity against HT-29 and HeLa cells. According to these results, Glaucium alkaloid extracts may have a favourable pharmacological profile in the treatment of $\mathrm{AD}$ and cancer. This study promotes greater awareness about the therapeutic use of $\mathrm{AChEi}$ in carcinogenetic diseases.

\section{Financial support and sponsorship: Nil.}

Conflict of Interests: There are no conflicts of interest.

\section{REFERENCES}

Ahmed F, Ghalib RM, Sasikala P, Mueen Ahmed KK. Cholinesterase inhibitors from botanicals. Phcpg Rev. 2013; 7: 21-30.

Albarracin SL, Stab B, Casas Z, Sutachan JJ, Samudio I, Gonzalez J, Gonzalo L, Capani F, Morales L, Barreto GE. Effects of natural antioxidants in neurodegenerative disease. Nutr Neurosci. 2012; 15: 1-9.

Al-Wakeel SAM, Mubasher M, Roberts M. Alkaloids from Glaucium corniculatum (L.) of Egyptian origin. Biochem. Syst. Ecol. 1995; 23: 337-338.

Alzheimer A. Uber eine eigenartige Erkrankung der Hirnrinde. Allg. Z. Psychiat. Psych.-Gericht. Med. 1907; 146-148 (German).

Babbar N. An introduction to alkaloids and their applications in pharmaceutical chemistry The Pharma Innovation Journal, 2015; 4: 74-75.

Bara II, Bara C, Capraru G, TrutaE. The possible ways of speciation in Papaveraceae family. Analele stiintifice ale Universitatii "Al.I.Cuza" din Iasi (serie noua), Sectiunea I, a. Gene. si Biol. Mol.Tom, 2007; 8: 223-233.

Bara II, Wellmann E. Papaver somniferum - achievements, certitudes, expectations. Acta Soc. Bot. Pol. 1985; 54: 179-187.

Bohm H, Nixdorf H. Qualitat und Qualitat von Morphinan Alkaloiden in Artbastarden der Gattung Papaver. Planta Medica, 1983; 48: 193-204.

Bradford MM. A rapid and sensitive method for the quantitation of microgram quantities of protein utilizing the principle of protein-dye binding. Anal Biochem. 1977; 72: 248-254.

Calissano P, Matrone C, Amadoro G. Apoptosis and in vitro Alzheimer disease neuronal models. Commun. Integr. Biol. 2009; 2: 163-169.

Cheng K, Samimi R, Xie G, Shant J, Drachenberg C, Wade M, Davis RJ, Nomikos G, Raufman JP. Acetylcholine release by human colon cancer cells mediates autocrine stimulation of cell proliferation. Am J Physiol Gastrointest Liver Physiol. 2008; 295: G591-7.

Das A, Shanker G, Nath C, Pal R, Singh S, Singh HK. A comparative study in rodents of standardized extracts of Bacopa monniera and Ginkgo biloba anticholinesterase and cognitive enhancing activities. Pharmacol Biochem Behav. 2002; 73: 893-900.

Das KP, Barone S. Neuronal differentiation in PC12 cells is inhibited by chlorpyrifos and its metabolites: is acetylcholinesterase inhibition the site of action? Toxicol Appl Pharmacol. 1999; 1: 217230.

Dhivya P, Sobiya M, Selvamani P, Latha S. An approach to Alzheimer's disease treatment with cholinesterase inhibitory Activity from Various Plant Species. Int J Pharm Tech Res. 2014; 6: 14501467.

Dodds HM, Hanrhan J, Rivory LR. The inhibition of acetylcholinesterase by irinotecan and related camptothecins: key structural properties and experimental variables, Anticancer Drugs Research, 2001; 16: 4-5; 239-246.

Doncheva T, Kostova N, Yordanova G, Saadi H, Akrib F, Dimitrov D, Philipov S. Comparison of alkaloid profile from Glaucium corniculatum (Papaveraceae) of Algerian and Bulgarian origin. Biochemical Systematics and Ecology, 2014; 56: 278-280.

Ellman GL, Courtney KD, Andres VJ, Featherstone RM. A new and rapid colorimetric determination of acetylcholinesterase activity. Biochem. Pharmacol. 1961; 7: 88-95.

Elufioye TO, Obuotor EM, Sennuga AT, Agbedahunsi JM, Adesanya SA. Acetylcholinesterase and butyrylcholinesterase inhibitory activity of some selected Nigerian medicinal plants. Brazilian Journal of Pharmacognosy, 2010; 20: 472-477. 
Exarchou V, Nenadis N, Tsimidou M, Gerothanassis IP, Troganis A, Boskou D. Antioxidant activities and phenolic composition of extracts from Greek oregano, Greek sage and summer savory. Journal of Agricultural \& Food Chemistry, 2002; 50: 5294 5299.

Fath T, Eidenmüller J, Brandt R. Tau-mediated cytotoxicity in a pseudohyperphosphorylation model of Alzheimer's disease. J. Neurosci. 2002; 22: 9733-9741.

Fedoroff S, Richardson A. 2001. Protocols for Neural Cell Culture 3rd ed. Humana Press, Totowa.

Fouche G, Cragg GM, Pillay P, Kolesnikova N, Maharaj VJ, et al. In vitro anticancer screening of South African plants. J Ethnopharmacol. 2008; 119: 455-46118678239.

Garaventa F, Piazza V, Zovko A, Turk T, Chelossi E, Falugi C, Aluigi MG, Angelini C, Trombino S, Gallus L, et al. Multiple functions of the cholinesterase inhibiting polyalkylpyridinium salts extracted from the marine sponge, Haliclona sarai. WSEAS Trans. Biol. Biomed. 2010; 7: 103-113.

Grassino M. ESMO Personalized Medicine" (Online Article).

https://www.esmo.org/content/download/20122/337223/file/ESMO-

Patient-Guide-Personalised-Cancer-Medicine.pdf. 2013 (accessed 8.2.2017).

Greene LA, Rein G. Release of $(3 \mathrm{H})$ norepinephrine from a clonal line of pheochromocytoma cells PC12) by nicotinic cholinergic stimulation. Brain Res. 1977; 138: 521-528.

Greene LA, Tischler AS. Establishment of a noradrenergic clonal line of rat adrenal pheochromocytoma cells which respond to nerve growth factor. Proc Natl Acad Sci USA. 1976; 73: 2424-2428.

Greene LA. Nerve growth factor prevents the death and stimulates the neuronal differentiation of clonal PC12 pheochromocytoma cells in serum-free medium. J Cell Biol. 1978; 78: $747-755$.

Houghton PJ, Howes MJ. Natural Products and Derivatives affecting neurotransmission relevant to Alzheimer's and Parkinson's disease. Neurosignals, 2005; 14: 6-22

Hyatt JL, Tsurkan L, Morton CL et al. Inhibition of acetylcholinesterase by the anticancer prodrug CPT-11. Chem Biol Interact, 2005; 157: 247-252

Ignatius MJ, Chandler CR, Shooter EM. Nerve growth factor-treated, neurite-bearing PC12 cells continue to synthesize DNA. J Neurosci.1985; 5: 343-351.

International Plant Name Index Available at: http://www.ipni.org/ [Accessed 8 March 2016].

Jacovina AT, Zhong F, Khazanova E, Lev E, Deora $\mathrm{AB}$, Hajjar KA. Neuritogenesis and the nerve growth factor-induced differentiation of PC-12 cells requires annexin II-mediated plasmin generation. J Biol Chem. 2001; 28: 49350-49358.

Jafarian A, Ghannadi A, Mohebi B. Cytotoxic effects of chloroform and hydroalcoholic extracts of aerial parts of Cuscuta chinensis and Cuscuta epithymum on Hela, HT29 and MDA-MB-468 tumor cells. Res Pharm Sci. 2014; 9: 115-122.

Jin QH, He HY, Shi YF, Lu H, Zhang XJ. Overexpression of acetylcholinesterase inhibited cell proliferation and promoted apoptosis in NRK cells. Acta Pharmacol Sin. 2004; 25: 1013-1021.

Lin JY, Tang CY. Determination of total phenolic and flavonoid contents in selected fruits and vegetables, as well as their stimulatory effects on mouse splenocyte proliferation. Food Chem. 2007; 101: 140-147.

Loizzo MR, Tundis R, Menichini F, Menichini F. Natural products and their derivatives as cholinesterase inhibitors in the treatment of neurodegenerative disorders: An update. Curr Med Chem. 2008; 15: 1209-1228
Lu JJ, Bao JL, Chen XP, Huang M, Wang YT. Alkaloids isolated from natural herbs as the anticancer agents. Evid Based Complement Alternat Med. 2012; 485042.

Ma R, Xiong N, Huang C, Tang Q, Hu B, Xiang J, Li G. Erythropoietin protects PC12 cells from beta-amyloid (25-35)-induced apoptosis via PI3K/Akt signaling pathway. Neuropharmacology, 2009; 56: 1027-1034.

Mahmoudi M, Rabe SZT, Ahi A, Emami SA. Evaluation of the Cytotoxic Activity of Different Artemisia Khorasanica Samples on Cancer Cell Lines Pharmacologyonline, 2009; 2: 778-786.

Mandegary A, Soodi M, Sharififar F, Ahmadi S. Anticholinesterase, antioxidant, and neuroprotective effects of Tripleurospermum disciforme and Dracocephalum multicaule. J Ayurveda Integr Med. 2014; 5: 162-166.

Martínez-López de Castro A, Nieto-Cerón S, Aurelio PC, et al. Cancer-associated differences in acetylcholinesterase activity in bronchial aspirates from patients with lung cancer. Clin Sci (Lond) 2008; 115: 245-253.

Mehta M, Adem A, Sabbagh M. New acetylcholinesterase inhibitors for Alzheimer's disease. Int J Alzheimers Dis. 2012; Article ID 728983

Miller-Jensen K, Janes KA, Brugge JS, Lauffenburger DA. Common effector processing mediates cell-specific responses to stimuli. Nature. 2007;448: 604-608.

Mohsen UA, Kocyigit-Kaymakcioglu B, Oruc-Emre EE Kaplancıklı ZA, Rollas S. Studies on Hydrazide-Hydrazones Derivatives as Acetylcholinesterase Inhibitors. MÜSBED, 2015; 1: $10-14$

Montenegro MF, Ruiz-Espejo F, Campoy FJ, et al. Cholinesterases are down-expressed in human colorectal carcinoma. Cell Mol Life Sci. 2006; 63: 2175-2182.

Mosmann T. Rapid colorimetric assay for cellular growth and survival: application to proliferation and cytotoxicity assays Journal of Immunological Methods, 1983; 65: 55-63.

Mukherjee PK, Kumar V, Mal M, Houghton PJ Acetylcholinesterase inhibitors from plants. Phytomedicine, 2007; 14: 289-300.

Murray AP, Faraoni MB, Castro MJ, Alza NP, Cavallaro V,.Natural AChE Inhibitors from Plants and their Contribution to Alzheimer's Disease Therapy. Curr Neuropharmacol. 2013; 11: 388 413.

Naaz H, Singh S, Pandey VP, Singh P, Dwivedi UN. Anticholinergic alkaloids as potential therapeutic agents for Alzheimer's disease: An in silico approach. Indian journal of biochemistry \& biophysics, 2013; 50: 120-125.

Novak V, Dolejs L, Slavik J. Alkaloids of the Papaveraceae. XLVIII. (-) Stylopine methohydroxide, a New Alkaloid from Glaucium corniculatum CURT. Collection Czechoslov. Chem. Commun, 1971; 37: 2804

Novak V, Dolejs L, Slavik J. Alkaloids of the Papaveraceae. XLVIII. (-)-Stylopine methohydroxide, a new alkaloid from Glaucium corniculatum CURT. Collect. Czech. Chem. Commun. 1972; 37: 3346-3349.

Obregon ADC, Schetinger MRC, Correa MM, Morsch VM, Da Silva JEP,.Martins MAP, Bonacorso HG, Zanatta N. Effects per se of organic solvents in the cerebral acetylcholinesterase of rats. Neurochem. Res. 2005; 30: 379-384.

Orhan I, Sener B, Choudhary MI, Khalid A. Acetylcholinesterase and butyrylcholinesterase inhibitory activity of some Turkish medicinal plants. J Ethnopharmaco. 2004; 91: 57-60.

Pera M, Camps P, Muñoz-Torrero D, Perez B, Badia A, Clos Guillen MV. Undifferentiated and differentiated PC12 cells protected by huprines against injury induced by hydrogen peroxide. PLoS ONE. 20013; 8. Article ID e74344, 2013. 
Perry NS, Houghton PG, Sampson J, Theolad AE, Hart S, Lis-balchin $\mathrm{M}$, et al. In vitro activities of Salvia lavandulaefolia (Spanish Sage) relevant to treatment of Alzheimer's disease. J Pharm Pharmacol. 2001; 53: 1347-56.

Perry NS, Houghton PG, Theolad AE, Jenner P, Perry EK. In vitro inhibition of human erythrocyte acetylcholinesterase by Salvia lavandulaefolia essential oil and constituent terpenes. J Pharm Pharmacol. 2000; 52: 895-902.

Phillipson JD, Gray AI, Askari AR, Khalil AA. Alkaloids from Iraqi species of Papaveraceae. J Nat Prod. 1981; 44: 296-307.

Rehman EU. Indigenous knowledge on medicinal plants, village Barali Kass and its allied areas, District Kotli Azad Jammu and Kashmir, Pakistan. Ethnobotanical Leaflets, 2006; 10: 254-264.

Rodrigues VG, Silva FC, Duarte LP, Takahashi JA, Matildes BLG, Silva GDF, Silva RR, Vierira-Filho SA. Pentacyclic Triterpenes from Maytenus Genus as Acetylcholinesterase Inhibitors. Int J Pharm Pharm Sci, 2014; 6: 918-920.

Roe CM, Behrens MI, Xiong C, Miller JP, Morris JC. Alzheimer's disease and cancer. Neurology, 2005; 64: 895-898.

Rowland JP, Rigby J, Harper AC, et al. Cardiovascular monitoring with acetylcholinesterase inhibitors: a clinical protocol. Adv Psychiatric Treat, 2007; 13: 178-84.

Sambamurti K, Shioi J, Anderson JP, Pappolla MA, Robakis NK. Evidence for intracellular cleavage of the Alzheimer's amyloid precursor in PC12 cells. J. Neurocsci. Res. 1992; 33: 319-329.

Sandhu FA. Model systems to study the $\beta$-amyloid protein of Alzheimer's disease Journal of the American Aging Association, 1993; 17: 7-11.

Schwartz PJ, Blundon JA, Adler EM. A Biochemical Assay for Acetylcholinesterase Activity in PC12 Cells, Sci STKE. 2007; 28: (394):tr2.

Sener B, Orhan I. Discovery of drug candidates from some Turkish plants and conservation of biodiversity. Pure Appl. Chem. 2005; 77: 53-64.

Shafiee A, Ghanbarpour A, Aknlaghi S. Alkaloids of Papaveraceae, XII. Alkaloids of Glaucium corniculatum Sucspecies Reflactum, Population Pol-Dokhtar. Journal of Netural Product, 1985; 48: 855-856.

Shamsa F, Monsef H, Ghamooshi R, Verdianrizi M. Spectrophotometric determination of total alkaloids in some Iranian medicinal plants. Thai J Pharm Sci. 2008; 32: 17-20.

Singleton VL, Orthofer R, Lamuela-Raventos RM. Analysis of total phenols and other oxidation substrates and antioxidants by means of Folin-Ciocalteu reagent. Meth. Enzymol. 1999; 299: 152178.

Small DH, Michaelson S, Sberna G. Non-classical actions of cholinesterases: Role in cellular differentiation, tumorigenesis and Alzheimer's disease. Neurochem Int. 1996; 28: 453-483.

Somani G, Kulkarni C, Shinde P, et al. In vitro acetylcholinesterase inhibition by psoralen using molecular docking and enzymatic studies. J Pharm Bioallied Sci. 2015; 7: 32-36.

Sriwiriyajan S, Ninpesh T, Sukpondma Y, Nasomyon T, Graidist P. Cytotoxicity screening of plants of genus Piper in breast cancer cell lines. Trop. J. Pharm. Res. 2014; 13: 921-928.

Syad AN, Devi KP. Botanics: a potential source of new therapies for Alzheimer's disease? Botanics: Targets and Therapy, 2014; 4: 11-26.

Tayeb HO, Yang HD, Price BH, Tarazi FI. Pharmacotherapies for Alzheimer's disease: Beyond cholinesterase inhibitors. Pharmacology \& Therapeutics, 2012; 134: 8-25.
Van Ooyen A. Competition in neurite outgrowth and the development of nerve connections. Progress in Brain Reserach, 2005; 147: 81-99.

Wang Y, Pan WL, Liang WC, Law WK, Tsz-Ming Ip D, Ng TB, Miu-Yee Waye M, Chi-Cheong Wan D. Acetylshikonin, a novel AChE inhibitor, inhibits apoptosis via upregulation of heme oxygenase-1 expression in SH-SY5Y cells. Evid Based Complement Alternat Med. 2013: 937370.

Weihe E, TaoCheng JH, Schafer MK, Erickson JD, Eiden LE. Visualization of the vesicular acetylcholine transporter in cholinergic nerve terminals and its targeting to a specific population of small synaptic vesicles. Proc Natl Acad Sci U S A. 1996; 93: 35473552.

White RS, Lipton RB, Hall $\mathrm{CB}$, Steinerman JR. Nonmelanoma skin cancer is associated with reduced Alzheimer disease risk. Neurology, 2013; 21: 1966-1972.

Wollen KA. Alzheimer's Disease: The Pros and Cons of Pharmaceutical, Nutritional, Botanical, and Stimulatory Therapies, with a Discussion of Treatment Strategies from the Perspective of Patients and Practitioners Alternative Med. Rev. 2010; 15: 223-244.

World Alzheimer Report 2015: The Global Impact of Dementia. https://www.alz.co.uk/research/world-report-2015 (accessed 13.08.2016).

Wszelaki N, Kuciun A, Karolina Kiss A. Screening of traditional European herbal medicines for acetylcholinesterase and butyrylcholinesterase inhibitory activity. Acta Pharm. 2010; 60: 119128.

Xi HJ, Wu RP, Liu JJ, Zhang LJ, Li ZS. Role of acetylcholinesterase in lung cancer. Thoracic Cancer, 2015; 6: 390398.

Xu HN, Shen ZX, Xiao J, Yang Y, Huang WD, Zhou ZM et al. Acetylcholinesterase overexpression mediated by oncolytic adenovirus exhibited potent anti-tumor effect. BMC Cancer, 2014; 14: 668.

Zha Y, Wang X, Wang T, et al. Acetylcholinesterase, a key prognostic predictor for hepatocellular carcinoma, suppresses cell growth and induces chemosensitization. Hepatology, 2011; 53: 493 503.

Zhang HY, Tang XC. Huperzine B, a novel acetylcholinesterase inhibitor, attenuates hydrogen peroxide induced injury in PC12 cells. Neurosci Lett. 2000; 292: 41-44.

Zhang HY. New insights into huperzine A for the treatment of Alzheimer's disease, Acta Pharmacologica Sinica. 2012; 33: 11701175.

Zhang XJ, Yang L, Zhao Q, et al. Induction of acetylcholinesterase expression during apoptosis in various cell types. Cell Death Differ. 2002; 9: 790-800.

How to cite this article:

Kocanci FG, Hamamcioglu B, Aslim B. The anti-AChE and antiproliferative Activities of Glaucium acutidentatum and Glaucium corniculatum Alkaloid Extracts. J App Pharm Sci, 2017; 7 (08): 191-200. 